\title{
Do Popular Norms Matter for Democratic Backsliding?
}

\author{
Dean Schafer \\ Department of Political Science \\ The Graduate Center, City University of New York \\ dschafer@gradcenter.cuny.edu
}

\begin{abstract}
:
This research takes the step of testing whether norms have a causal impact on the decline of democratic institutions. I use a dyadic analysis that draws on data from the European and World Values Survey and Polity IV. I find that popularly held norms do not matter, but that the norms of economic elites do. There are two theoretical points driving these findings. One, the decisions of political elites is disproportionately influenced by voters wealthier than the median. The resources commanded by economic elites make them more important than the average citizen, and accordingly, their interests and values are also more important. In effect, the selectorate is considerably smaller than the full voting population. The diminished importance of the regular voting citizen is especially the case in declining democracies. Two, wealthy elites have historically been opposed to democratic concessions. Due to greater levels of income inequality, elites' opposition to democracy, along with their relative power, has increased. Therefore, their normative attitudes are increasingly likely to translate into democratic decline.
\end{abstract}

Prepared for presentation at the American Political Science Association annual meeting, Washington DC, 2019 


\section{Introduction}

Do norms matter? Recently, we've seen a renewed interest in analyzing norms and their importance for democracy’s survival (Foa and Mounk 2016, 2017; Howe 2017; Wike and Fetterolf 2018). For example, Levitsky and Ziblatt (2018) describe norms such as mutual toleration and forbearance as the "guardrails of democracy." These studies have shown undeniably that norms are declining. What is less clear is what has caused this decline, or what effect it has. Put differently, while authors frequently assert that norms matter, we do not know specifically how or why they matter. If, as is frequently theorized, democratic backsliding is an elite-driven process (Bermeo 2003, 2016; Levitsky and Ziblatt 2018; Mainwaring and PérezLiñán 2013) then why does it matter if democratic norms are declining among the general population? Wike and Fetterolf $(2018,176)$ argue that "if citizens are open to nondemocratic approaches, would-be autocrats may find opportunities to transgress the unwritten rules that help hold democracies together." But, how much evidence can we observe in support of this argument?

This research takes the step of testing whether norms have a causal impact on the decline of democratic institutions. I use a dyadic analysis that draws on data from the European and World Values Survey and Polity IV. I am especially interested in the effect we see in national states where democratic norms have declined, as measured by people's openness to nondemocratic solutions to political issues. I expect that popularly held norms do not matter, but that the norms of economic elites do. There are two theoretical points driving this expectation. One, the decisions of political elites is disproportionately influenced by voters wealthier than the median. The resources commanded by wealthy elites make them more important than the average citizen, and accordingly, their interests and values are also more important. In effect, the 
selectorate is considerably smaller than the full voting population (Bueno de Mesquita et al. 2005). The diminished importance of the regular voting citizen is especially the case in declining democracies. Two, following closely on one, wealthy elites have historically been opposed to democratic concessions (Acemoglu and Robinson 2006). I expect that due to greater levels of income inequality, elites' opposition to democracy, along with their relative power, has increased. Therefore, their normative attitudes are increasingly likely to translate into democratic decline.

\section{Theoretical Framework}

\section{Declining Norms and Democratic Backsliding}

Democracy is in trouble. We know this. Foa and Mounk $(2017,2016)$ document the longterm trend in the decline of democratic norms in twenty three countries. Data from the European and World Values Surveys shows that people are increasingly critical of the good democracy does, and are more open to non-democratic solutions to political issues, such as rule by "unelected experts," "an authoritarian government," or "a strong leader that does not have to bother with parliament or elections" (Foa and Mounk 2017, 7). On the ground, one third of the world's population lives in a declining democracy (Lührmann et al. 2018), and, academics writing on the topic have variously described democracy as "deconsolidating" (Foa and Mounk 2016, 2017), "stagnating” (Mainwaring and Bizzarro 2019; Carothers 1997), “eroding” (Puddington 2008), "rolling back" (Diamond 2008), "backsliding" (Bermeo 2016), or even “careening" (Slater 2013). Undergirding these terms is a similar logic: democratic institutions remain outwardly intact, while the overall quality of democracy declines, or at least fails to 
improve beyond a low level. Further, gradual changes mean that no one moment clearly marks when regime transition occurs. But what role, if any, do popular norms play in this process of democratic decline?

Several important works have challenged the idea that the preferences of the average voter matters, even in full democracies such as the United States (Gilens and Page 2014; Weber 2019; Winters 2011). Economic elites can leverage their influence to set the political agenda, lobby policy makers, shape policy outcomes on contested issues, and quite possibly, sway public preferences. Winters (2011) analysis shows how economic elites have leveraged their resources for political advantage throughout history. Coupled with this is evidence of the ability of political elites to shape political identities: by instrumentalizing nationalistic and xenophobic discourses, they increase the salience of ethnic cleavages and inculcate intolerance and anti-democratic attitudes (Brass 1991; Brubaker 1996; Posner 2004). Additionally, the literature on democratization and democratic breakdown that does look at norms, tends to focus on elites (Levitsky and Ziblatt 2018; Mainwaring and Pérez-Liñán 2013), though Linz does argue that the norms of the average citizen matters during periods of political and economic crisis (Linz 1978). Given these premises, we should expect that popular democratic norms do not matter. If the policy preferences of the average citizen are not reflected in the platforms of the political parties in their country, we should hardly expect that their normative attitudes would shape the political regime itself. 


\section{Expectations About Elite Attitudes}

Distributional conflict theory states that elites are consistently more anti-democratic than the average citizen (Boix 2003; Acemoglu and Robinson 2000, 2006). Elites oppose democracy because of its redistributive aspects. Therefore, the greater the demand for economic redistribution, and the threat it poses to their position, - such as in highly unequal societies - the greater elites will resist the institutionalization of a democratic regime. However, historical developments - such as from agrarian to industrialized economies - transformed the interests of economic elites, making democracy less threatening. Further, modernization theory states that economic development and increasing levels of education should instill actors with democratic norms (Inglehart and Welzel 2005). Indeed, greater levels of development correlate strongly with stable democracies (Przeworski and Limongi 1997; Przeworski et al. 2000). Built into this logic of democracy and development is that powerful actors begin to see their interests as being served by democracy, and so buy into its legitimacy as a political system. But, the predictive power of economic factors for democratization and democratic stability have weakened in more recent decades (Boix 2011; Boix, Miller, and Rosato 2013; Foa 2018). If Mainwaring and Pérez-Liñán $(2013,32)$ are right that "structural variables such as poverty and inequality do not go very far toward explaining [the democratic] preferences" of elites, then we should expect more proximate causes such as polarization, institutional legacies, or international pressure to have greater importance.

While I do not discount the effect of short- and middle-term factors on norms, the approach in this paper attempts to thread the needle between structural economic factors, more proximate, normative attitudes, and gradual regime shifts. Economic factors do shape normative attitudes, both of elites and the general population. Income inequality increases economic elites' 
opposition to democracy because it both increases the threat of economic redistribution and their relative tax burden, amplifying their sense of resentment. It also increases their relative power. The breaking up of unions and the weakening of social safety nets during an era of austerity politics reduces the capacity for popular mobilization. While grievances are present, people's ability to organize around them is limited, increasing feelings of political and economic insecurity, and their frustration with politics (Korpi and Palme 2003; Korpi 2006; Tarrow 2011). ${ }^{1}$

The proximate cause in this equation is the norms of economic elites, whose preferences more quickly get translated into real change. When economic elites are opposed to democracy their relative political power provides them the means to realize their preferences. Outright authoritarianization is generally too costly, and entails too much risk, both for political and economic elites. Instead we should expect the gradual hollowing out of democratic institutions, following the pattern of democratic backsliding.

\section{Methodology}

To test the expectations drawn from the literature I built a dataset combining information from the World Values Survey (WVS), European Values Survey (EVS), and Polity IV (Marshall, Gurr, and Jaggers; EVS 2016; Inglehart et al.). WVS and EVS surveys were conducted across the years 1981 to 2014. Economic data was from the Penn World Table (Feenstra, Inklaar, and Timmer 2019), and GINI measures for income inequality is from The Standardized World

\footnotetext{
${ }^{1}$ This, ironically, opens a space for populist leaders, who also represent a threat to democratic institutions, and who are also usually, themselves, wealthy elites. Unfortunately, an investigation of this element lies beyond the scope of the paper.
} 
Income Inequality Database (Solt 2019). The dataset covers a total of 77 distinct countries across approximately 20 years, from 1995 to 2014, for a total of 304 country years.

\section{Proxies for Norms of Authoritarian Tolerance and Economic Elites}

The WVS and EVS contains a question that asks whether "having a strong leader who doesn't have to bother with parliament or elections" is a very good, fairly good, fairly bad, or very bad thing. Answers are coded from 1 to 4, with 1 being "very good," 2 being "fairly good," 3 being "fairly bad" and 4 being "very bad." I use this question as a proxy for norms of "authoritarian tolerance." I chose this question because it is direct and descriptive and does not require respondents to interpret abstract concepts such as democracy - the definition of which political scientists do not even agree on - when registering their approval or disapproval. Also, importantly, the question is asked in most surveys since 1995, thereby maximizing the opportunity for observing variation over time. I interpret increases in authoritarian tolerance to represent decreases in democratic norms, and vice versa. See Appendix for the full wording of the strong leader question and other questions relevant to democracy and income on the WVS and EVS. The WVS and EVS surveys are conducted in waves approximately every five years. For each country year, I calculated the mean score for this question based on the responses of the country's whole population, the top fifty percent of income earners (who, for shorthand I refer to as the "Middle Class"), and top twenty percent of income earners. ${ }^{2}$ I use the attitudes of the top twenty percent of income earners to proxy for the attitudes of economic elites.

\footnotetext{
2 Top ten percent of income earners would have been preferable but was not statistically feasible due to small sample size.
} 


\section{Dyadic Analysis}

My aim is to measure changes in norms of authoritarian tolerance and to test the effect of this change on changes in regime. Using the mean scores for authoritarian tolerance, my dataset consists of dyads of "before" and "after" points. For example, if there is survey information for Argentina for years 1995, 1999, 2006 and 2013, then that means three dyads are possible: 19951999, 1999-2006, and 2006-2013. Dyads of corresponding Polity IV scores are paired to the "authoritarian tolerance" dyads. I do not expect changes in norms to translate very quickly into institutional change. Therefore, Polity IV scores are delayed by four years, making the corresponding dyads 1999-2003, 2003-2010, 2010-2017. A four-year delay was chosen as a rough approximation for election cycles. I expect elections to be critical junctures around which norms are realized in political change. To these paired dyads I also add dyads measuring change in the Gini coefficient and change in GDP per capita as control variables. The dataset contains a total of 178 dyads measuring change in norms across the whole population, 130 dyads for the top fifty percent of income earners, and 127 dyads for economic elites.

This research design draws on the advantages of both most-different and most-similar systems design. It compares across geographic regions, thereby controlling for the effects of different regional systems. The variables themselves measure change within the same country, thereby controlling for country-level political context, minimizing the interference of factors within the same political system. Structural factors such GDP, inequality, national institutions, education-levels, culture, or political identities change infrequently, and then only slowly.

This first cut of the data follows five steps. First, I look at the effect of changes in norms in isolation. Second, I look at whether the norms of economic elites carry more weight in polities that are more unequal than the mean. Third, I look at the effect of changes in norms with the 
added control variables of changes in inequality and GDP per capita. For both steps I used ordered logistical regressions because of the incremental changes in polity scores: most changes range between -2 to 3 . Fourth, as a further robustness check, I look at static Polity IV scores as they relate to norms, inequality and GDP per capita. The greater range of polity scores means that an ordinary least squares regression is appropriate. The advantage of this step is that it provides a greater number of observations: 287 country years for the whole population, 236 for the top fifty percent of income earners, 232 for economic elites. The disadvantage is that it ignores the political context. For this reason, I include a second regression that uses the polity score from four years earlier as a control variable. Fifth, I look at factors that explain authoritarian tolerance. I use an OLS regression to analyze the effects of inequality on norms. I also include GDP per capita as a control. This step also makes it possible to control for reverse causality by testing the effect of regime type on norms. In other words, I can control for whether people's expressed norms simply reflect the regime they live in.

\section{Results}

The results of the regression in table 1 are an initial step towards establishing a relationship between norms and their consequence for political regimes. This ordered logistic regression looks at the effect of changes in norms on changes in polity scores within 77 countries covering a twenty-year period, from 1995 to 2014 . This regression isolates two factors - change in norms and change in polity score - and therefore helps us determine whether a decline in democratic norms helps explain democratic backsliding. 
Table 1 - Change in Polity Score Over Change in Norms

\begin{tabular}{|c|c|c|c|}
\hline VARIABLES & $\begin{array}{c}(1) \\
\text { Model } 1 \\
\end{array}$ & $\begin{array}{c}(2) \\
\text { Model } 2 \\
\end{array}$ & $\begin{array}{c}(3) \\
\text { Model } 3 \\
\end{array}$ \\
\hline Whole Population & $\begin{array}{c}0.48 \\
(0.53) \\
\mathbf{0 . 3 6 9}\end{array}$ & & \\
\hline Middle Class & & $\begin{array}{c}0.50 \\
(0.55) \\
\mathbf{0 . 3 6 5} \\
\end{array}$ & \\
\hline Economic Elites & & & $\begin{array}{c}0.66+ \\
(0.40) \\
\mathbf{0 . 0 9 8} \\
\end{array}$ \\
\hline Observations & 164 & 120 & 117 \\
\hline
\end{tabular}

We can see that norms of authoritarian tolerance of the whole population do not appear to matter, neither do the norms of the middle class. Only changes in the norms of economic elite show up as significant. These findings accord with the conclusions of Gilens and Page (2014), Winters (2011), and Weber (2019). Regardless of the specific political system, economic elites have an oversized ability to dominate politics in service of their interests. The evidence above further suggests that the norms of economic elites are translated into changes to the political regime itself.

But, does the power of economic elites to effect regime change increase in polities that are more unequal? A rough way to test for this is to look at states with a Gini coefficient greater than the mean (in other words, those states that are more unequal than the average). Limiting the regression to polities with a Gini higher than 35 produces the results seen in table 2 . 
Table 2 - Change in Polity Score

\begin{tabular}{lc}
\hline & $(1)$ \\
VARIABLES & Model 1 \\
\hline & \\
Change in Norms of & $0.73+$ \\
Economic Elites & $(0.42)$ \\
& $\mathbf{0 . 0 8 5}$ \\
\hline
\end{tabular}

\begin{tabular}{c} 
Observations \\
\hline Standard errors in parentheses \\
Pvalues in bold \\
$* * \mathrm{p}<0.01, * \mathrm{p}<0.05,+\mathrm{p}<0.1$
\end{tabular}

Figure 1 - Predicted Effect of Change in Authoritarian Tolerance on Change in Polity Score

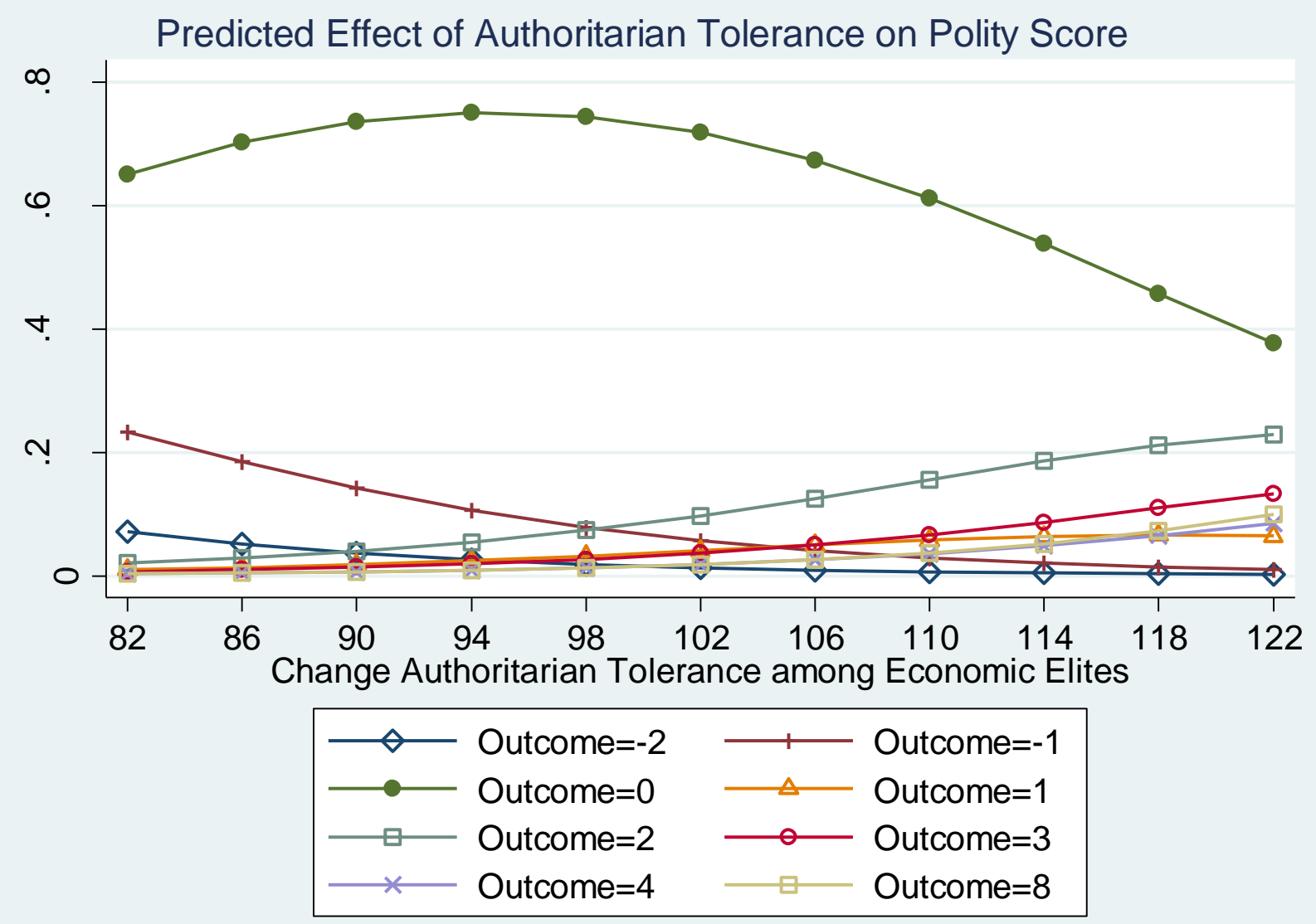


The p-value and coefficient both improve, indicating support for the hypothesis that inequality does increase the relative power of economic elites. A margins plot of the potential outcomes (a rise or fall in polity score) helps us visualize the results of the regression in table 2 (see figure 1). Each line represents a potential increase or decrease in the polity score. The $\mathrm{x}$-axis measures the level of change in authoritarian tolerance among economic elites. A score of 100 represents no change. Moving to the left represents an increased level of authoritarian tolerance, and to the right represents a decreased level of authoritarian tolerance. Unsurprisingly, an outcome of 0 - that is, no change the polity score - is the mostly likely outcome regardless of normative changes. However, the probability of a change in polity score increases with the level of change in authoritarian tolerance. While that change in likelihood might not look dramatic, a .3 probability of regime change towards authoritarianism (combining outcomes -1 and -2 ), due to a change in elite norms, is a considerable risk, and one that, as Linz reminds us, would affect the lives of millions (Linz 1978). We can also see that changes in norms are particularly effective at explaining small, incremental shifts in regime, the kinds of shifts that define democratic backsliding (Bermeo 2016; Waldner and Lust 2018).

That said, the above models might be omitting economic variables that have stronger explanatory power than elite norms. Economic events such as the global recession in 2008 hit quickly, and are argued to have propelled the popularity of populist leaders in Europe (Judis 2016). For this reason, the regression evidenced in table 3 controls for changes in inequality and change in GDP per capita. 
Table 3 - Change in Polity Score

\begin{tabular}{|c|c|c|c|}
\hline VARIABLES & $\begin{array}{c}(1) \\
\text { Model } 1 \\
\end{array}$ & $\begin{array}{c}(2) \\
\text { Model } 2 \\
\end{array}$ & $\begin{array}{c}(3) \\
\text { Model } 3 \\
\end{array}$ \\
\hline $\begin{array}{l}\text { Change in Norms of } \\
\text { Whole Population }\end{array}$ & $\begin{array}{c}0.67 \\
(0.55) \\
\mathbf{0 . 2 1 7}\end{array}$ & --- & --- \\
\hline $\begin{array}{l}\text { Change in Norms of } \\
\text { Middle Class }\end{array}$ & --- & $\begin{array}{c}0.50 \\
(0.58) \\
\mathbf{0 . 3 9 4}\end{array}$ & --- \\
\hline $\begin{array}{l}\text { Change in Norms of } \\
\text { Economic Elites }\end{array}$ & --- & -- & $\begin{array}{c}0.68 \\
(0.42) \\
\mathbf{0 . 1 0 3} \\
\end{array}$ \\
\hline Change in Gini & $\begin{array}{c}0.07 \\
(0.13) \\
\mathbf{0 . 5 9 8}\end{array}$ & $\begin{array}{c}0.05 \\
(0.13) \\
\mathbf{0 . 6 8 1}\end{array}$ & $\begin{array}{c}0.06 \\
(0.13) \\
\mathbf{0 . 6 4 5}\end{array}$ \\
\hline $\begin{array}{l}\text { Change in GDP Per } \\
\text { Capita }\end{array}$ & $\begin{array}{l}-0.03 \\
(0.04) \\
\mathbf{0 . 5 3 0}\end{array}$ & $\begin{array}{l}-0.03 \\
(0.05) \\
\mathbf{0 . 4 7 7}\end{array}$ & $\begin{array}{l}-0.04 \\
(0.05) \\
\mathbf{0 . 4 0 8}\end{array}$ \\
\hline Observations & 158 & 116 & 114 \\
\hline
\end{tabular}

Neither changes in inequality nor GDP per capita have a significant effect on changes in the polity score. However, the measure for the authoritarian tolerance of economic elites also loses significance. The p-value for this variable falls just above highest cutoff point at .103 , rendering its significance questionable. There is evidence that the norms of economic elites matter for regime change, but the null hypothesis cannot be rejected in this case.

\section{Robustness Check}

As a further robustness check of the above findings I looked at static polity scores as they relate to democratic norms (see table 4). This OLS regression takes a country's polity score as 
the dependent variable, delayed four years like the above regressions, and looks at the effect of authoritarian tolerance, controlling for inequality and affluence using the Gini coefficient and GDP per capita from the same year. Because this model, unlike the dyads, does not control for country-level political context, I ran a second, otherwise identical regression, that includes the polity score as a control variable. The control polity score is from four years before that in the dependent variable. The result of the second regression can be seen in models 4,5 , and $6 .^{3}$

Table 4 - Polity Score

\begin{tabular}{|c|c|c|c|c|c|c|}
\hline VARIABLES & $\begin{array}{c}\text { (1) } \\
\text { Model 1 } \\
\end{array}$ & $\begin{array}{c}(2) \\
\text { Model } 2 \\
\end{array}$ & $\begin{array}{c}(3) \\
\text { Model } 3 \\
\end{array}$ & $\begin{array}{c}(4) \\
\text { Model } 4 \\
\end{array}$ & $\begin{array}{c}(5) \\
\text { Model } 5 \\
\end{array}$ & $\begin{array}{c}6) \\
\text { Model } 6 \\
\end{array}$ \\
\hline $\begin{array}{l}\text { Norms of } \\
\text { Whole Population }\end{array}$ & $\begin{array}{c}0.44 \\
(0.69) \\
\mathbf{0 . 5 2 1}\end{array}$ & --- & --- & $\begin{array}{l}0.56+ \\
(0.33) \\
\mathbf{0 . 0 9 5}\end{array}$ & --- & --- \\
\hline Norms of Middle Class & --- & $\begin{array}{c}0.57 \\
(0.76) \\
\mathbf{0 . 4 5 6} \\
\end{array}$ & --- & --- & $\begin{array}{c}0.60 \\
(0.38) \\
\mathbf{0 . 1 2 0} \\
\end{array}$ & --- \\
\hline Norms of Economic Elites & --- & --- & $\begin{array}{l}1.19+ \\
(0.64) \\
\mathbf{0 . 0 6 4} \\
\end{array}$ & --- & --- & $\begin{array}{l}0.56+ \\
(0.33) \\
\mathbf{0 . 0 9 3} \\
\end{array}$ \\
\hline Gini & $\begin{array}{c}0.02 \\
(0.04) \\
\mathbf{0 . 6 4 9} \\
\end{array}$ & $\begin{array}{c}0.04 \\
(0.05) \\
\mathbf{0 . 4 5 4} \\
\end{array}$ & $\begin{array}{c}0.03 \\
(0.05) \\
\mathbf{0 . 4 4 8} \\
\end{array}$ & $\begin{array}{l}-0.00 \\
(0.02) \\
\mathbf{0 . 8 3 8} \\
\end{array}$ & $\begin{array}{l}-0.01 \\
(0.02) \\
\mathbf{0 . 8 1 1} \\
\end{array}$ & $\begin{array}{l}-0.01 \\
(0.02) \\
\mathbf{0 . 7 2 3} \\
\end{array}$ \\
\hline GDP per capita & $\begin{array}{c}0.13 * * \\
(0.02) \\
\mathbf{0 . 0 0 0}\end{array}$ & $\begin{array}{c}0.14 * * \\
(0.03) \\
\mathbf{0 . 0 0 0}\end{array}$ & $\begin{array}{c}0.12 * * \\
(0.03) \\
\mathbf{0 . 0 0 0} \\
\end{array}$ & $\begin{array}{l}-0.01 \\
(0.01) \\
\mathbf{0 . 6 4 6} \\
\end{array}$ & $\begin{array}{l}-0.01 \\
(0.01) \\
\mathbf{0 . 6 3 6} \\
\end{array}$ & $\begin{array}{l}-0.01 \\
(0.01) \\
\mathbf{0 . 5 9 4} \\
\end{array}$ \\
\hline Polity Score & --- & --- & --- & $\begin{array}{c}0.87 * * \\
(0.03) \\
\mathbf{0 . 0 0 0} \\
\end{array}$ & $\begin{array}{c}0.86 * * \\
(0.04) \\
\mathbf{0 . 0 0 0} \\
\end{array}$ & $\begin{array}{c}0.85 * * \\
(0.04) \\
\mathbf{0 . 0 0 0}\end{array}$ \\
\hline Constant & $\begin{array}{c}2.55 \\
(2.62) \\
0.330 \\
\end{array}$ & $\begin{array}{c}1.11 \\
(3.04) \\
0.714 \\
\end{array}$ & $\begin{array}{l}-0.16 \\
(2.70) \\
0.953\end{array}$ & $\begin{array}{l}-0.19 \\
(1.26) \\
0.883\end{array}$ & $\begin{array}{l}-0.21 \\
(1.53) \\
0.889\end{array}$ & $\begin{array}{c}0.12 \\
(1.39) \\
0.934\end{array}$ \\
\hline $\begin{array}{l}\text { Observations } \\
\text { Adjusted R-squared }\end{array}$ & $\begin{array}{c}249 \\
0.150\end{array}$ & $\begin{array}{c}204 \\
0.143\end{array}$ & $\begin{array}{c}200 \\
0.145\end{array}$ & $\begin{array}{c}249 \\
0.803\end{array}$ & $\begin{array}{c}204 \\
0.784\end{array}$ & $\begin{array}{c}200 \\
0.772\end{array}$ \\
\hline
\end{tabular}

\footnotetext{
${ }^{3}$ I also ran a regression using the polity score from the immediately preceding year as a control variable (see Appendix, Table 8). In that regression all other variables lose significance. However, the p-values of norms approach significance.
} 
Figure 2 - Margins plot, Predicted Effect of Authoritarian Tolerance on Polity Score

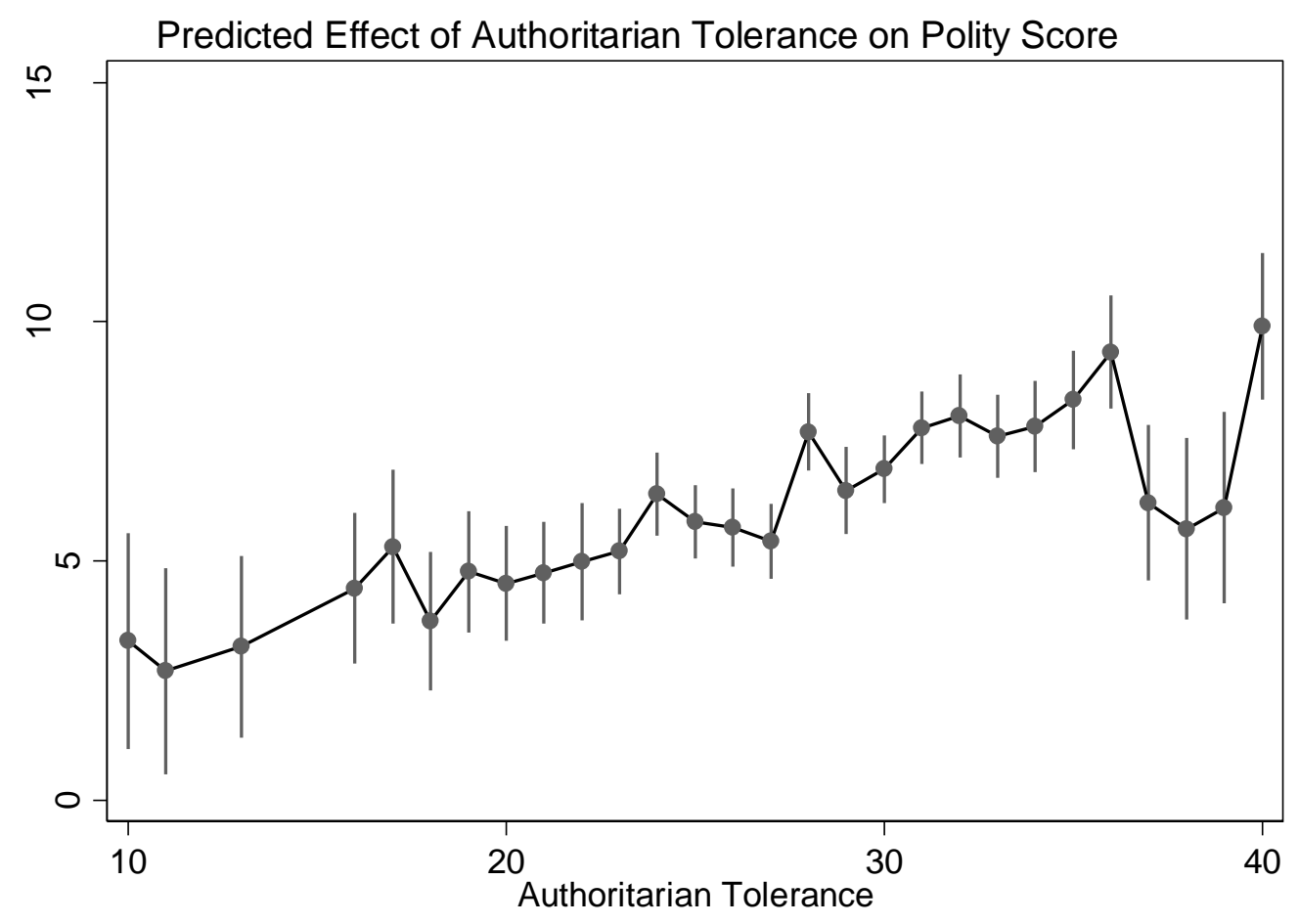

Controlling for GDP per capita, the norms of economic elites are still significant, while the norms of the rest of the population are not. Surprisingly, inequality does not correlate with regime type in this model. We see similar results in models 4 through 6, though GDP per capita loses its significance. The normative attitudes of economic elites maintain significance. ${ }^{4} \mathrm{~A}$ visualization of the relationship in model 3 can be seen in figure 2 above. On the $x$-axis, "Authoritarian Tolerance," a score of 40 corresponds to saying a "strong leader who doesn't have to deal with elections or parliament" is a "very bad" thing. 30 corresponds to an answer of "fairly bad", 20 to "fairly good" and 10 corresponds to "very good." In the graph, the predicted impact of norms on regime type becomes apparent. Complete disavowal of an authoritarian style

\footnotetext{
${ }^{4}$ I do not have a theoretical explanation for why the authoritarian tolerance of the whole population shows up as significant. Future research will need to address this.
} 
leader by economic elites correlates to full democracy, whereas attitudes that approve of an authoritarian style leader correlates to a slide into anocracy. Controlling for both GDP per capita and the polity score from four years earlier, the norms of economic elites appear to have a strong and significant impact on regime type.

Are Economic Elites Authoritarian?

The results above provide evidence in support of the hypothesis that the norms of economic elites matter disproportionately for regime change, but they are not evidence that the preferences of economic elites are dangerously authoritarian. Nor do they explain the current period of democratic retrenchment that began as early as 1997 by some accounts (Carothers 1997). Distributional conflict theory posits that economic elites are hostile to democracy because of its redistributive effects (Acemoglu and Robinson 2006, 2000; Boix 2003). But, despite evidence that economic modernization and increasing income levels are decreasingly important for democratization (Foa 2018; Boix 2011; Boix, Miller, and Rosato 2013), we cannot discount the possibility that good economic times have an ameliorative effect on democratic norms. My dataset shows that during the period of my analysis there was a net decline in democratic norms among economic elites (see table 5). What is driving this trend?

Table 5 - Summary of Change Variables

\begin{tabular}{cccccc}
\hline Variable & Obs & Mean & Std. Dev & Min & Max \\
\hline Change in Norms of Economic Elites & 127 & -0.038 & 0.507 & -1.805 & 2.190 \\
Change in Gini & 183 & -0.027 & 1.708 & -7.6 & 5.3 \\
Change in GDP per capita & 193 & 3.784 & 4.531 & -2.802 & 32.349
\end{tabular}


Besides a decline in democratic norms, another observable trend in the data is an increase in economic inequality, while GDP per capita increased considerably (see table 5). Table 6 below provides the results of a regression examining the effects these variables have on norms of authoritarian tolerance. ${ }^{5}$ The polity score is also included to control for the effects of regime type on norms. To clarify, this regression does not look at the effects of change, but rather looks at the correlation between authoritarian tolerance (the dependent variable) and GDP, inequality, and regime type during all country years in the data set.

Table 6 - Authoritarian Tolerance

\begin{tabular}{lccc}
\hline & $(1)$ & $(2)$ & $(3)$ \\
VARIABLES & All Pop & Middle & Elites \\
\hline Gini Coefficient & $-0.01^{*}$ & $-0.01^{*}$ & $-0.01^{*}$ \\
& $(0.00)$ & $(0.00)$ & $(0.00)$ \\
& 0.040 & 0.010 & 0.034 \\
\hline Polity Score & -0.00 & -0.00 & 0.01 \\
& $(0.01)$ & $(0.01)$ & $(0.01)$ \\
& 0.832 & 0.959 & 0.249 \\
\hline GDP per capita & $0.01^{* *}$ & $0.01^{* *}$ & $0.01 * *$ \\
& $(0.00)$ & $(0.00)$ & $(0.00)$ \\
& 0.000 & 0.000 & 0.000 \\
\hline Constant & $2.87^{* *}$ & $3.04^{* *}$ & $2.94 * *$ \\
& $(0.16)$ & $(0.18)$ & $(0.21)$ \\
& 0.000 & 0.000 & 0.000 \\
\hline Observations & 251 & 206 & 202 \\
Adjusted R-squared & 0.172 & 0.163 & 0.170 \\
\hline
\end{tabular}

Standard errors in parentheses

Pvalues below standard errors

$* * \mathrm{p}<0.01, * \mathrm{p}<0.05,+\mathrm{p}<0.1$

\footnotetext{
${ }^{5}$ I also conducted a test to confirm the absence of reverse causality, which is included in the appendix (see table 7). It tests the effect of changes in GDP per capita, inequality and regime on changes in norms. None of the variables came up significant.
} 
Figure 3 - Predicted Effect of Inequality on Authoritarian Tolerance of Economic Elites

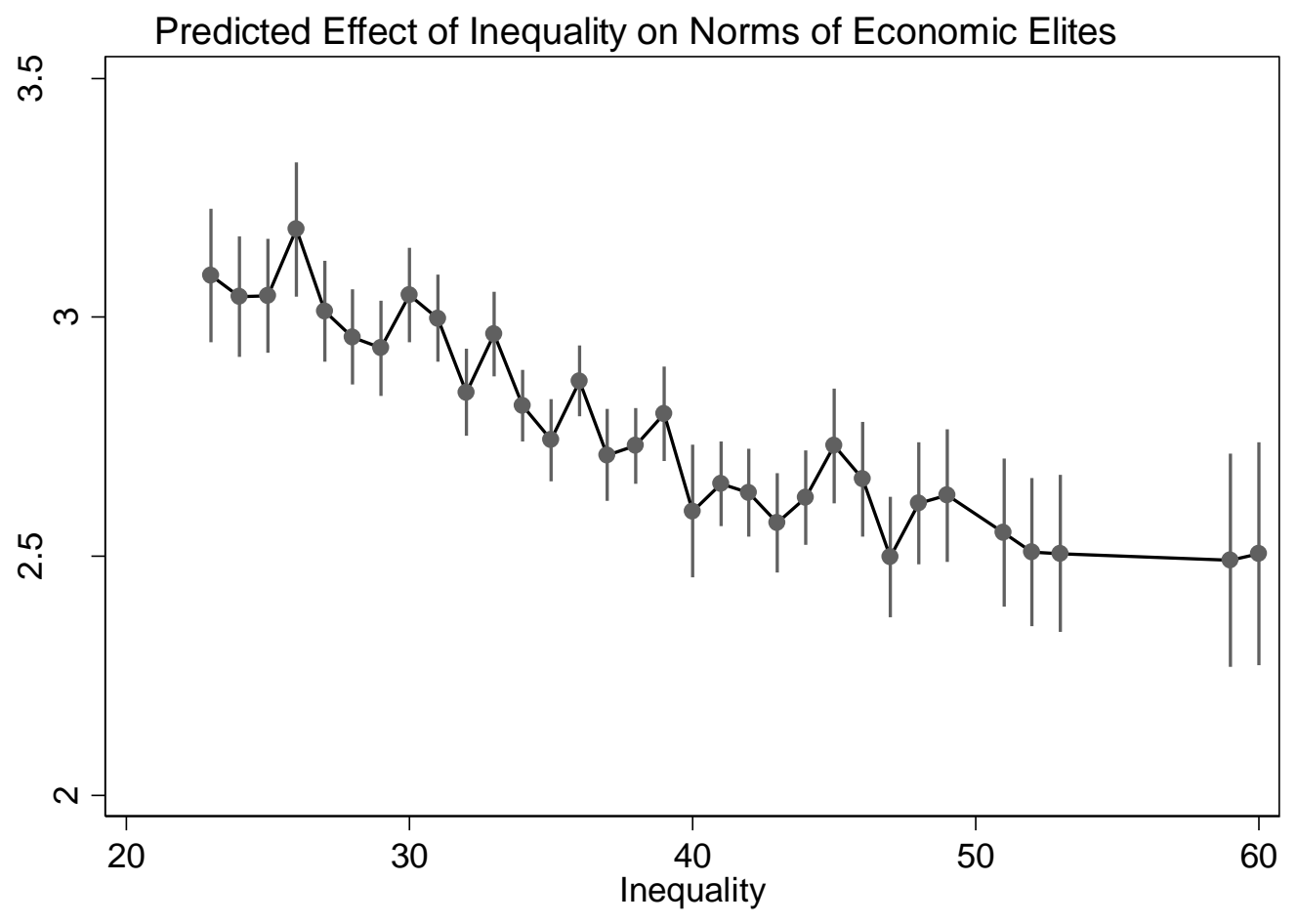

Controlling both for GDP per capita and regime type, income inequality has a significant effect on norms of authoritarian tolerance among all sectors of the population. A visualization of the relationship for economic elites can be seen in figure 3. In the graph, on the y-axis, "3" corresponds to saying that it is "fairly bad" to have a political system with a strong leader who doesn't have to bother with parliament or elections, where as "2" corresponds to the answer "fairly good". We can see that near the middle of the Gini index on the x-axis, the predicted answer moves closer to "good". As countries become more unequal, economic elites are more likely to be hostile to democracy. Under the same conditions, those elites are also more likely to shape the direction of the political regime. The evidence suggests that income inequality, 
transmitted through the actions of economic elites, is a root cause of democratic decline.

Economic elites function as a causal mechanism linking inequality and regime change. ${ }^{6}$

\section{Discussion}

Inequality Matters

The results above provide preliminary evidence of the impact of rising income inequality and shifting norms of economic elites on regime change. The norms of the average citizen do not appear to bear on the trajectory of the political regime. The norms of economic elites, on the other hand, do matter. And, the norms of economic elites appear to carry more weight in states that are more unequal than the mean. Further, income inequality appears to be a root cause of democratic backsliding: the normative preferences of economic elites are considerably more authoritarian in states that are more unequal economically.

Global trends require generalizable answers. A strength of this analysis is that it draws on data from 77 countries across twenty years. While process tracing might better observe the connection and logic of the timing between changes in norms and regime changes, the use of country-level dyads helps control for a range of structural factors, thereby improving the generalizability of the results. When one third of the world's population lives in a declining democracy, the need to identify global, generalizable causes becomes even more urgent (Lührmann et al. 2018). There is mounting evidence that the economic model preferred by Washington-based institutions - which has therefore served as the basis for countless economic

\footnotetext{
${ }^{6}$ It is also worth noting that rising income inequality may well be offsetting the beneficial effects of overall economic growth.
} 
reforms globally since the 1980s - produces economic growth at the expense of increasing inequality (Williamson 1990, 2000; Stiglitz 2002; Serra and Stiglitz 2008; Harvey 2007). Therefore, understanding the political consequences of that economic model will help us explain the occurrence of similar phenomena, such as the increasing popularity of strong man, "populist" leaders, across a diverse set of countries and regions.

The weakness of this statistical analysis is that it is a blunt instrument. It runs roughshod over the subtle changes that define democratic backsliding. Further, because of issues of sample size, it was necessary to use the opinions of the top twenty percent of income earners as a proxy for the attitudes of economic elites, who, given the nature of economic inequality and the disparate wealth accumulation of the past few decades, is actually comprised of the top five, or even top one, percent of income earners.

Changes in norms rarely translate directly or quickly into changes in political regimes. Levitsky and Ziblatt's (2018) single case study of the United States describes a process of normative decline that began as early as the Gingrich Revolution in 1994, resulting finally twenty years later in a change in polity score and a president who harbors expressly authoritarian values. Another example, drawing from my own research, is the case of Turkey. There, a dramatic decline in democratic norms occurred in 2001-2002, likely the result of a severe economic crisis (Schafer 2019). Recep Tayyip Erdogan became the prime minister the next year. He has always been a "strong man" style leader, but he did not try to institutionally consolidate power until over ten years later, beginning in 2013. While it is likely that changes in norms facilitated his authoritarian move, the substantial time lag means that it is difficult to fully capture the connection between norms and regime in a statistical model. I therefore expect that 
the relationship between democratic norms (either of the whole population, or of economic elites specifically) and regime type is stronger than this analysis suggests.

Going forward, the conclusions in this paper can be strengthened by building a more sophisticated statistical model that provides a more complete picture of shifts in democratic norms. My proxy for “authoritarian tolerance” relies on one question about people's preference for strong leaders. An index of "democratic norms" that draws on a larger range of questions regarding people's democratic preferences might provide a more robust test of my hypothesis. Further, future research building on the conclusions here should also better account for the delay between norms and real institutional change. For example, elections are a key critical juncture. The 2016 elections in the US provided the opportunity for a shift in the Republican Party's messaging and a realignment of its electoral coalition that relied more than before on racial signaling. Similarly, Turkey's dramatic shift into authoritarianism occurred in 2015, when the success of the Kurdish-issue-focused People's Democratic Party (the HDP) in parliamentary elections spurred the government to reignite the war with the PKK and crack down on dissenting media outlets.

I anticipate that a closer look at the causal mechanisms between economic inequality and democratic decline would shed light on the nature of populism, especially regarding populists' claim to be representing "the people". I suspect the causal direction is top down, rather than bottom up. Populists are usually themselves wealthy elites. And, there is a body of work showing that when political elites instrumentalize identity issues they escalate intolerance and antidemocratic attitudes (Brass 2001; Brubaker 1996; Posner 2004; Snyder 2000). I suspect that 
rather than responding to the demands of the people, anti-democratic "populists" are shaping those demands while simultaneously courting the support of economic elites. ${ }^{7}$

\section{Conclusion}

These findings support the assertion that the norms of the average citizen do not matter for democratic backsliding. On the other hand, the norms of economic elites do matter for changes to the political regime. Further, in polities with greater income inequality, the norms of elites both carry more weight, and are more authoritarian. Normative attitudes are also most effective at explaining incremental regime changes: a shift of 1, 2 or 3 points on the polity score. This suggests that economic elites' normative attitudes are a useful proximate variable for predicting democratic backsliding, but that elites' norms reflect deeper, structural factors.

This research contributes to the literature on democratic backsliding by testing the causal effect of popularly held norms. My findings help clarify why economic growth, as measured by per capita income, has decreased in its importance for promoting democracy (Boix 2011; Boix, Miller and Rosato 2012). My analysis contends that not only are wealthy elites anti-democratic in their normative attitudes, but also that their attitudes are those most frequently reflected in the backsliding of democratic institutions. Turning distributive conflict theory on its head, I expect that increased levels of income inequality strengthens anti-democratic groups, drawing on realizations that authors writing about resource mobilization and power resource theory made

\footnotetext{
${ }^{7}$ For a different take see, Mudde's (2010) persuasive analysis of the supply-side factors driving the populist radical right in Europe.
} 
much earlier (Tarrow 1994; McAdam, Tarrow, and Tilly 2001; Korpi 2006; Korpi and Palme 2003). While my research does not test these theories, it draws on their insights to explain variation in the data and point toward potential areas of research. Future research, capable of examining these cases in greater nuance, is necessary to understand how regular people's interpretation of their rational economic interests is conditioned by what they see as politically possible. 


\section{References}

Acemoglu, Daron, and James A. Robinson. 2000. “Democratization or Repression?” European Economic Review 44 (4-6): 683-93.

Acemoglu, Daron, and James A Robinson. 2006. Economic Origins of Dictatorship and

Democracy. Cambridge; New York: Cambridge University Press.

Bermeo, Nancy. 2003. Ordinary People in Extraordinary Times: The Citizenry and the Breakdown of Democracy. Princeton University Press.

—. 2016. “On Democratic Backsliding.” Journal of Democracy 27 (1): 5-19. https://doi.org/10.1353/jod.2016.0012.

Boix, Carles. 2003. Democracy and Redistribution. Cambridge University Press.

—. 2011. "Democracy, Development, and the International System." American Political Science Review 105 (4): 809-28. https://doi.org/10.1017/S0003055411000402.

Boix, Carles, Michael Miller, and Sebastian Rosato. 2013. “A Complete Data Set of Political Regimes, 1800-2007.” Comparative Political Studies 46 (12): 1523-54. https://doi.org/10.1177/0010414012463905.

Brass, Paul R. 1991. Ethnicity and Nationalism: Theory and Comparison. Sage Publications (CA).

Brubaker, Rogers. 1996. Nationalism Reframed: Nationhood and the National Question in the New Europe. Cambridge University Press.

Bueno de Mesquita, Bruce, Alastair Smith, James D. Morrow, and Randolph M. Siverson. 2005. The Logic of Political Survival. MIT press.

Carothers, Thomas. 1997. “Democracy without Illusions.” Foreign Affairs 76 (1): 85-99. https://doi.org/10.2307/20047911. 
Diamond, Larry. 2008. "The Democratic Rollback-the Resurgence of the Predatory State." Foreign Aff. 87: 36.

EVS. 2016. European Values Study 2008: Integrated Dataset (EVS 2008). Version 4.0.0. GESIS Data Archive, Cologne. http://dx.doi.org/10.4232/1.12458.

Feenstra, Robert C., Robert Inklaar, and Marcel P. Timmer. 2019. "Penn World Table 9.1.” Groningen Growth and Development Centre. https://doi.org/10.15141/s50t0r.

Foa, Roberto Stefan. 2018. "Modernization and Authoritarianism." Journal of Democracy 29 (3): 129-40.

Foa, Roberto Stefan, and Yascha Mounk. 2016. "The Democratic Disconnect.” Journal of Democracy 27 (3): 5-17. https://doi.org/10.1353/jod.2016.0049.

—. 2017. "The Signs of Deconsolidation." Journal of Democracy 28 (1): 5-15. https://doi.org/10.1353/jod.2017.0000.

Gilens, Martin, and Benjamin I. Page. 2014. "Testing Theories of American Politics: Elites, Interest Groups, and Average Citizens." Perspectives on Politics 12 (3): 564-81. https://doi.org/10.1017/S1537592714001595.

Harvey, David. 2007. A Brief History of Neoliberalism. Oxford University Press, USA. Howe, Paul. 2017. “Eroding Norms and Democratic Deconsolidation.” Journal of Democracy 28 (4): 15-29. https://doi.org/10.1353/jod.2017.0061.

Inglehart, R, C Haerpfer, A Moreno, C Welzel, K Kizilova, J Diez-Medrano, M Lagos, P Norris, E Ponarin, and B Puranen. n.d. "World Values Survey: All Rounds - Country-Pooled Datafile 1981-2014.” Madrid: JD Systems Institute. Accessed July 11, 2019. http://www.worldvaluessurvey.org/WVSDocumentationWVL.jsp. 
Inglehart, Ronald, and Christian Welzel. 2005. Modernization, Cultural Change, and Democracy: The Human Development Sequence. Cambridge University Press.

Judis, John B. 2016. Original: The Populist Explosion: How The Great Recession Transformed American And European Politics.

Korpi, Walter. 2006. "Power Resources and Employer-Centered Approaches in Explanations of Welfare States and Varieties of Capitalism: Protagonists, Consenters, and Antagonists." World Politics 58 (2): 167-206.

Korpi, Walter, and Joakim Palme. 2003. "New Politics and Class Politics in the Context of Austerity and Globalization: Welfare State Regress in 18 Countries, 1975-95.” American Political Science Review 97 (3): 425-46.

Levitsky, Steven, and Daniel Ziblatt. 2018. How Democracies Die. First edition. New York: Crown.

Linz, Juan J. 1978. The Breakdown of Democratic Regimes: Crisis, Breakdown and Reequilibration. An Introduction. Johns Hopkins University Press.

Lührmann, Anna, Valeriya Mechkova, Sirianne Dahlum, Laura Maxwell, Moa Olin, Constanza Sanhueza Petrarca, Rachel Sigman, Matthew C. Wilson, and Staffan I. Lindberg. 2018. "State of the World 2017: Autocratization and Exclusion?" Democratization 25 (8): 1321-40. https://doi.org/10.1080/13510347.2018.1479693.

Mainwaring, Scott, and Fernando Bizzarro. 2019. "The Fates Of Third-Wave Democracies." Journal of Democracy 30 (1): 99-113. https://doi.org/10.1353/jod.2019.0008. Mainwaring, Scott, and Aníbal Pérez-Liñán. 2013. Democracies and Dictatorships in Latin America: Emergence, Survival, and Fall. Cambridge University Press. 
Marshall, Monty G, Ted Gurr, and Keith Jaggers. n.d. "Polity IV Annual Time Series 1800-2017 (P4v2017).” Polity IV Project, Center for Systemic Peace.

Mudde, Cas. 2010. “The Populist Radical Right: A Pathological Normalcy.” West European Politics 33 (6): 1167-86. https://doi.org/10.1080/01402382.2010.508901.

Posner, Daniel N. 2004. "The Political Salience of Cultural Difference: Why Chewas and Tumbukas Are Allies in Zambia and Adversaries in Malawi.” American Political Science Review 98 (4): 529-45.

Przeworski, Adam, Michael E. Alvarez, Jose Antonio Cheibub, and Fernando Limongi. 2000. Democracy and Development: Political Institutions and Well-Being in the World, 19501990. Vol. 3. Cambridge University Press.

Przeworski, Adam, and Fernando Limongi. 1997. "Modernization: Theories and Facts." World Politics 49 (2): 155-83.

Puddington, Arch. 2008. “Is the Tide Turning?” Journal of Democracy 19 (2): 61-73. https://doi.org/10.1353/jod.2008.0021.

Schafer, Dean. 2019. "Unencumbered Democrats: Why Some Vote for Strong Men.” CUNY Working Paper, 47.

Serra, Narcís, and Joseph E. Stiglitz. 2008. The Washington Consensus Reconsidered: Towards a New Global Governance. OUP Oxford.

Slater, Dan. 2013. “Democratic Careening.” World Politics 65 (4): 729-63. https://doi.org/10.1017/S0043887113000233.

Solt, Frederick. 2019. "Measuring Income Inequality Across Countries and Over Time: The Standardized World Income Inequality Database.”

Stiglitz, Joseph E. 2002. Globalization and Its Discontents. Vol. 500. New York Norton. 
Tarrow, Sidney G. 2011. Power in Movement: Social Movements and Contentious Politics. Cambridge University Press.

Waldner, David, and Ellen Lust. 2018. "Unwelcome Change: Coming to Terms with Democratic Backsliding.” Annual Review of Political Science 21 (1): 93-113. https://doi.org/10.1146/annurev-polisci-050517-114628.

Weber, Till. 2019. "Discreet Inequality: How Party Agendas Embrace Privileged Interests." CUNY Working Paper, 66.

Wike, Richard, and Janell Fetterolf. 2018. “Liberal Democracy’s Crisis of Confidence.” Journal of Democracy 29 (4): 136-50. https://doi.org/10.1353/jod.2018.0069.

Williamson, John. 1990. "What Washington Means by Policy Reform.” Latin American Adjustment: How Much Has Happened 1: 90-120.

—. 2000. "What Should the World Bank Think about the Washington Consensus?" The World Bank Research Observer 15 (2): 251-64.

Winters, Jeffrey A. 2011. Oligarchy. Cambridge University Press. 


\section{Appendix}

$\underline{\text { Tables }}$

Table 7 - Change in Authoritarian Tolerance

\begin{tabular}{lccc}
\hline & $(1)$ & $(2)$ & $(3)$ \\
VARIABLES & AllPop & Middle Class & Economic Elites \\
\hline \multirow{2}{*}{ Change in Polity Score } & -0.01 & -0.01 & 0.01 \\
& $(0.01)$ & $(0.01)$ & $(0.02)$ \\
& 0.569 & 0.659 & 0.683 \\
\hline Change in GDP per capita & -0.00 & -0.01 & -0.00 \\
& $(0.01)$ & $(0.01)$ & $(0.01)$ \\
& 0.481 & 0.105 & 0.871 \\
\hline Change in Gini & -0.02 & -0.02 & -0.02 \\
& $(0.02)$ & $(0.02)$ & $(0.03)$ \\
& 0.205 & 0.275 & 0.464 \\
\hline Observations & 160 & 118 & 116 \\
Adjusted R-squared & -0.004 & 0.005 & -0.020 \\
\hline dard errors in parentheses $\mid$ Pvalues are below standard errors $\left.\right|^{* *} \mathrm{p}<0.01, * \mathrm{p}<0.05,+\mathrm{p}<0.1$
\end{tabular}

Table 8 - Polity Score

(1) (2) (3)

\begin{tabular}{lccc} 
VARIABLES & Model 1 & Model 1 & Model 1 \\
\hline \multirow{2}{*}{ Norms of Economic Elites } & 0.22 & & \\
& $(0.16)$ & & \\
& $\mathbf{0 . 1 8 3}$ & & \\
Norms of Middle Class & & 0.31 & \\
& & $(0.19)$ & \\
\hline Norms of Whole & & & 0.102 \\
Population & & & $(0.16)$ \\
& & & $\mathbf{0 . 1 6 0}$ \\
\hline & -0.00 & 0.00 & 0.00 \\
Gini & $(0.01)$ & $(0.01)$ & $(0.01)$ \\
& $\mathbf{0 . 9 2 3}$ & $\mathbf{0 . 9 5 6}$ & $\mathbf{0 . 9 8 2}$ \\
\hline & -0.01 & -0.01 & -0.01 \\
GDP Per Capita & $(0.01)$ & $(0.01)$ & $(0.01)$ \\
& $\mathbf{0 . 2 6 1}$ & $\mathbf{0 . 2 2 4}$ & $\mathbf{0 . 2 5 2}$ \\
\hline Polity Score, & $0.98^{* *}$ & $0.98^{* *}$ & $0.98^{* *}$ \\
1 year previous & $(0.02)$ & $(0.02)$ & $(0.02)$ \\
& $\mathbf{0 . 0 0 0}$ & $\mathbf{0 . 0 0 0}$ & $\mathbf{0 . 0 0 0}$ \\
\hline Observations & 200 & 204 & 249 \\
Adjusted R-squared & 0.945 & 0.947 & 0.952 \\
\hline
\end{tabular}

Standard errors in parentheses $\mid$ Pvalues are in bold $\mid * * \mathrm{p}<0.01, * \mathrm{p}<0.05,+\mathrm{p}<0.1$ 


\section{World Values Survey Questions}

\section{SHOW CARD 66 - READ OUT AND CODE ONE ANSWER PER LINE}

Q66 I'm going to describe various types of political systems and ask what you think about each as a way of governing this country. For each one, would you say it is a very good, fairly good, fairly bad or very bad way of governing this country?

\begin{tabular}{|c|c|c|c|c|c|c|c|}
\hline & & very good & fairly good & fairly bad & very bad & $\mathrm{DK}$ & NA \\
\hline v225 & $\begin{array}{l}\text { Having a strong leader who does not have to bother } \\
\text { with parliament and elections }\end{array}$ & 1 & 2 & 3 & 4 & 8 & 9 \\
\hline v226 & $\begin{array}{l}\text { Having experts, not government, make decisions } \\
\text { according to what they think is best for the country }\end{array}$ & 1 & 2 & 3 & 4 & 8 & 9 \\
\hline v227 & Having the army rule the country & 1 & 2 & 3 & 4 & 8 & 9 \\
\hline v228 & Having a democratic political system & 1 & 2 & 3 & 4 & 8 & 9 \\
\hline
\end{tabular}

SHOW CARD 67 - READ OUT AND CODE ONE ANSWER PER LINE

Q67 I'm going to read off some things that people sometimes say about a democratic political system. Could you please tell me if you agree strongly, agree, disagree or disagree strongly, after I read each of them?

\begin{tabular}{|c|l|c|c|c|c||c|c|}
\cline { 2 - 7 } \multicolumn{2}{c|}{} & $\begin{array}{c}\text { agree } \\
\text { strongly }\end{array}$ & agree & disagree & $\begin{array}{c}\text { disagree } \\
\text { strongly }\end{array}$ & DK & NA \\
\hline v229 & $\begin{array}{l}\text { Democracy may have problems but it's better than } \\
\text { any other form of government }\end{array}$ & 1 & 2 & 3 & 4 & 8 & 9 \\
\hline v230 & In democracy, the economic system runs badly & 1 & 2 & 3 & 4 & 8 & 9 \\
\hline & $\begin{array}{l}\text { Democracies are indecisive and have too much } \\
\text { squabbling }\end{array}$ & 1 & 2 & 3 & 4 & 8 & 9 \\
\hline
\end{tabular}


SHOW CARD 125

Q125 Here is a list of incomes. We would like to know in what income group your household is, counting all wages, salaries, pensions and incomes from other sources. Could you please tell me the letter of the group your household falls into, after taxes and other deductions.

(v353)

\begin{tabular}{|c|c|c|c|c|}
\hline & & Approximate WEEKLY & Approximate MONTHLY & Approximate ANNUAL \\
\hline 1 & $A$ & Less than $£ 26$ per week & Less than $£ 111$ per month & Less than $£ 1,328$ per year \\
\hline 2 & $\mathrm{~B}$ & $\begin{array}{c}\text { Between } £ 26 \text { and } £ 51 \text { per } \\
\text { month }\end{array}$ & $\begin{array}{l}\text { Between } £ 111 \text { and } £ 221 \text { per } \\
\text { month }\end{array}$ & $\begin{array}{l}\text { Between } £ 1,328 \text { and } £ 2,656 \\
\text { per year }\end{array}$ \\
\hline 3 & $\mathrm{C}$ & $\begin{array}{c}\text { Between } £ 51 \text { and } £ 85 \text { per } \\
\text { week }\end{array}$ & $\begin{array}{c}\text { Between } £ 221 \text { and } £ 369 \text { per } \\
\text { month }\end{array}$ & $\begin{array}{c}\text { Between } £ 2,656 \text { and } £ 4,427 \\
\text { per year }\end{array}$ \\
\hline 4 & $\mathrm{D}$ & $\begin{array}{c}\text { Between } £ 85 \text { and } £ 170 \text { per } \\
\text { week }\end{array}$ & $\begin{array}{c}\text { Between } £ 369 \text { and } £ 738 \text { per } \\
\text { month }\end{array}$ & $\begin{array}{c}\text { Between } £ 4,427 \text { and } £ 8,854 \\
\text { per year }\end{array}$ \\
\hline 5 & $\mathrm{E}$ & $\begin{array}{l}\text { Between } £ 170 \text { and } £ 255 \\
\text { per week }\end{array}$ & $\begin{array}{c}\text { Between } £ 738 \text { and } £ 1,107 \text { per } \\
\text { month }\end{array}$ & $\begin{array}{c}\text { Between } £ 8,854 \text { and } £ 13,281 \\
\text { per year }\end{array}$ \\
\hline 6 & $\mathrm{~F}$ & $\begin{array}{c}\text { Between } £ 255 \text { and } £ 341 \\
\text { per week }\end{array}$ & $\begin{array}{l}\text { Between } £ 1,107 \text { and } £ 1,476 \\
\text { per month }\end{array}$ & $\begin{array}{c}\text { Between } £ 13,281 \text { and } £ 17,708 \\
\text { per year }\end{array}$ \\
\hline 7 & G & $\begin{array}{c}\text { Between } £ 341 \text { and } £ 426 \\
\text { per week }\end{array}$ & $\begin{array}{c}\text { Between } £ 1,476 \text { and } £ 1,845 \\
\text { per month }\end{array}$ & $\begin{array}{c}\text { Between } £ 17,708 \text { and } £ 22,135 \\
\text { per year }\end{array}$ \\
\hline 8 & $\mathrm{H}$ & $\begin{array}{c}\text { Between } £ 426 \text { and } £ 511 \\
\text { per week }\end{array}$ & $\begin{array}{c}\text { Between } £ 1,845 \text { and } £ 2,214 \\
\text { per month }\end{array}$ & $\begin{array}{c}\text { Between } £ 22,135 \text { and } £ 26,562 \\
\text { per year }\end{array}$ \\
\hline 9 & I & $\begin{array}{l}\text { Between } £ 511 \text { and } £ 851 \\
\text { per week }\end{array}$ & $\begin{array}{c}\text { Between } £ 2,214 \text { and } £ 3,689 \\
\text { per month }\end{array}$ & $\begin{array}{c}\text { Between } £ 26,562 \text { and } £ 44,271 \\
\text { per year }\end{array}$ \\
\hline 10 & $\mathrm{~J}$ & $\begin{array}{l}\text { Between } £ 851 \text { and } £ 1,277 \\
\text { per week }\end{array}$ & $\begin{array}{l}\text { Between } £ 3,689 \text { and } £ 5,534 \\
\text { per month }\end{array}$ & $\begin{array}{c}\text { Between } £ 44,271 \text { and } £ 66,406 \\
\text { per year }\end{array}$ \\
\hline 11 & $\mathrm{~K}$ & $\begin{array}{c}\text { Between } £ 1,277 \text { and } \\
£ 1,703 \text { per week }\end{array}$ & $\begin{array}{c}\text { Between } £ 5,534 \text { and } £ 7,378 \\
\text { per month }\end{array}$ & $\begin{array}{c}\text { Between } £ 66,406 \text { and } £ 88,541 \\
\text { per year }\end{array}$ \\
\hline 12 & $\mathrm{~L}$ & $£ 1,703$ or more per week & $£ 7,378$ or more per month & $£ 88,541$ or more per year \\
\hline
\end{tabular}

88 - don't know (spontaneous)

99 - no answer (spontaneous)

(Note: This is an example. Each survey and wave year provides a country specific income scale) 